\title{
Low-Frequency Stimulation of Afferent A $\delta$-Fibers Induces Long- Term Depression at Primary Afferent Synapses with Substantia Gelatinosa Neurons in the Rat
}

\author{
J. Sandkühler, ${ }^{1,2}$ J. G. Chen, ${ }^{2}$ G. Cheng, ${ }^{1}$ and M. Randić ${ }^{1}$ \\ ${ }^{1}$ Department of Veterinary Physiology and Pharmacology, lowa State University, Ames, lowa 50011, and 2/nstitute of \\ Physiology II, University of Heidelberg, 69120 Heidelberg, Germany
}

Impulses in primary afferent nerve fibers may produce short- or long-lasting modifications in spinal nociception. Here we have identified a robust long-term depression (LTD) of synaptic transmission in substantia gelatinosa neurons that can be induced by low-frequency stimulation of primary afferent $A \delta$ fibers. Synaptic transmission between dorsal root afferents and neurons in the substantia gelatinosa of the spinal cord dorsal horn was examined by intracellular recording in a transverse slice dorsal root preparation of rat spinal cord. Conditioning stimulation of dorsal roots with 900 pulses given at $1 \mathrm{~Hz}(10 \mathrm{~V}$, $0.1 \mathrm{msec}$ ) produced LTD of EPSP amplitudes in substantia gelatinosa neurons to $41 \pm 10 \%$ of control that lasted for at least $2 \mathrm{hr}$. When A- and C-fibers were recruited, conditioning stimulation was as effective as A-fiber stimulation alone. After LTD, synaptic strength could be increased to its original level by applying a second, high-frequency tetanic stimulus to the dor- sal root, indicating that LTD is reversible and not attributable to damage of individual synapses. Bath application of the $\mathrm{GABA}_{\mathrm{A}}$ receptor antagonist bicuculline and glycine receptor antagonist strychnine did not affect LTD. When NMDA receptors were blocked by bath application of D-2-amino-5-phosphonovaleric acid, LTD was abolished or strongly reduced. Loading substantia gelatinosa neurons with $\mathrm{Ca}^{2+}$ chelator BAPTA also blocked or reduced LTD. After incubation of slices with calyculin A, a selective and membrane permeable inhibitor of protein phosphatases 1 and 2A, LTD was not attenuated. We propose that this form of LTD may be relevant for long-lasting segmental antinociception after afferent stimulation.

Key words: primary afferents; synaptic transmission; spinal cord; substantia gelatinosa; pain; antinociception; afferent stimulation; long-term depression; NMDA; BAPTA; calyculin A
Thermal and nociceptive sensory information is encoded by fine, thinly myelinated $\mathrm{A} \delta$-fibers and unmyelinated $\mathrm{C}$-fibers. They terminate in the superficial spinal dorsal horn (Gobel and Falls, 1979; Light and Perl, 1979) where they make exclusively excitatory synaptic contacts with second-order neurons. It is now well established that afferent stimulation may facilitate (Woolf et al., 1988) or inhibit (Melzack and Wall, 1965; Le Bars et al., 1979; Pomeranz and Bibic, 1988) transmission of nociceptive information in the spinal dorsal horn. Electrophysiological studies in spinalized primates (Wagman and Price, 1969; Chung et al., 1984), cats (Handwerker et al., 1975; Chung et al., 1983), and rats (Woolf and Wall, 1982) have shown that cutaneous A-fiber stimulation selectively inhibits $\mathrm{C}$-fiber- and noxious stimulus-evoked excitation of dorsal horn neurons. This segmental inhibition (Chung et al., 1983, 1984) may considerably outlast the duration of conditioning stimulation (Urban and Nashold, 1978; Pomeranz and Warma, 1988). The spinal mechanisms underlying this prolonged antinociception are still not well understood, although pre- and postsynaptic mechanisms are likely to contribute to the inhibition.

GABA and glycine and their receptors are abundant in the

Received May 5, 1997; accepted June 4, 1997.

This work was supported by National Institutes of Health Grant NS-26352 and National Science Foundation Grant IBN-9209462 to M.R. and by Grants SA 435/9-1 and SA 435/10-1 from the Deutsche Forschungsgemeinschaft to J.S.

Correspondence should be addressed to Dr. J. Sandkühler, Universität Heidelberg, II. Physiologisches Institut, Im Neuenheimer Feld 326, D-69120 Heidelberg, Germany.

Copyright (C) 1997 Society for Neuroscience $0270-6474 / 97 / 176483-09 \$ 05.00 / 0$ spinal cord, including the substantia gelatinosa (lamina II) (Mitchell et al., 1993). GABA acting on $\mathrm{GABA}_{\mathrm{A}}$ receptors may directly hyperpolarize cells by increasing $\mathrm{Cl}^{-}$conductances, and acting on $\mathrm{GABA}_{\mathrm{B}}$ receptors it may increase $\mathrm{K}^{+}$conductances leading to hyperpolarization of spinal dorsal horn neurons (Kangrga et al., 1991). GABA may presynaptically inhibit release of neurotransmitters by reduction of $\mathrm{Ca}^{2+}$ entry. Spinal glycine receptor channels may have properties similar to those of $\mathrm{GABA}_{\mathrm{A}}$ receptor channels (Bormann et al., 1987). Spinal blockade of $\mathrm{GABA}_{\mathrm{A}}$ and glycine receptors may lead to central sensitization and touch-evoked allodynia (Sivilotti and Woolf, 1994).

Activity in the presynaptic terminal may directly alter synaptic strength. These activity-dependent changes in synaptic efficiency exist at various sites in the brain. Long-term potentiation (LTP) (Bliss and Collingridge, 1993) and long-term depression (LTD) (Dudek and Bear, 1992; Mulkey et al., 1993) of synaptic strength have been studied in detail in the hippocampus and other brain areas (Linden, 1994). It has been shown that both phenomena require elevation in free cytosolic $\mathrm{Ca}^{2+}$ concentration in the postsynaptic neuron (Malenka et al., 1988, 1992; Hartell, 1996). L-glutamate or a related excitatory amino acid has been proposed as a transmitter of fast EPSP at primary afferent synapses with dorsal horn neurons on the basis of both biochemical and physiological evidences (King et al., 1988; Schneider and Perl, 1988; Yoshimura and Jessell, 1990; Yoshimura and Nishi, 1995). The activation of the two known classes of glutamate receptors, ionotropic and metabotropic (Watkins and Evans, 1981; Honore et al., 1988), may lead to an elevation of free cytosolic $\mathrm{Ca}^{2+}$ levels (MacDermott et al., 1986; Ascher and Nowak, 1987; Mayer and 
Westbrook, 1987; Pin and Duvoisin, 1995). Recently it has been shown that brief, tetanic stimulation of dorsal roots may lead to either LTP or LTD of synaptic transmission in primary afferents in the superficial spinal dorsal horn in a slice preparation from young rats (Randić et al., 1993). High-frequency stimulation in the dorsomedial white matter of young rat spinal cord in vitro may result in LTP or LTD, or it may have no effect on amplitudes of field potentials recorded in intermediate gray matter (Pockett, 1995). In intact animals, tetanic stimulation of afferent C-fibers may produce a robust LTP of C-fiber-evoked field potentials in the superficial spinal dorsal horn (Liu and Sandkühler, 1995, 1997). Here we describe a new form of long-lasting modification of synaptic transmission in primary afferents: a robust LTD of A $\delta$-fiber-evoked mono- or polysynaptic EPSPs in substantia gelatinosa neurons by low-frequency stimulation of dorsal roots in vitro. This inhibition may be involved in long-lasting afferentinduced segmental antinociception.

\section{MATERIALS AND METHODS}

Preparation of spinal cord slice. Transverse slices were obtained from young Sprague Dawley rats of both sexes (18-28 d old). Under deep ether anesthesia, segments of the lumbosacral $\left(\mathrm{L}_{4}-\mathrm{S}_{1}\right)$ spinal cord were removed, with long $(8-15 \mathrm{~mm})$ dorsal roots attached. A Vibratome (Series 1000, Polysciences, Warrington, PA) was used to cut several transverse slices $(400-500 \mu \mathrm{m})$ immediately rostral and caudal to the dorsal root entry zones in oxygenated Krebs-bicarbonate solution at $4^{\circ} \mathrm{C}$. All slices were incubated for at least $1 \mathrm{hr}$ in a solution that was equilibrated with $95 \% \mathrm{O}_{2}, 5 \% \mathrm{CO}_{2}$ and contained (in $\mathrm{mM}$ ): $\mathrm{NaCl} \mathrm{124,} \mathrm{KCl} 5$, $\mathrm{KH}_{2} \mathrm{PO}_{4} 1.2, \mathrm{CaCl}_{2} 2.4, \mathrm{MgSO}_{4} 1.3, \mathrm{NaHCO}_{3} 26$, glucose $10, \mathrm{pH} 7.4$, at $34 \pm 1{ }^{\circ} \mathrm{C}$. The first slice was then transferred into a recording chamber where it was superfused with an oxygenated bath medium at $3-4 \mathrm{ml} / \mathrm{min}$. The bath medium was identical to the incubation solution except for a lower concentration of potassium ions $(1.9 \mathrm{~mm})$. In some experiments a two-compartment system was used. The spinal cord slice was superfused with bath solution, and the dorsal root was placed in parafin oil for electrical stimulation and for recording compound action potentials in $\mathrm{A} \delta$ - and $\mathrm{C}$-fibers.

Recording and stimulation techniques. The substantia gelatinosa was identified as a translucent band in the superficial dorsal horn when viewed under a dissecting microscope with transmitted illumination (see arrow in Fig. $1 A$ ). Conventional electrophysiological technique was used for intracellular recording from substantia gelatinosa neurons, with single glass microelectrodes filled with $4 \mathrm{~m}$ potassium acetate, $\mathrm{pH} 7.2$ (DC resistance $115-180 \mathrm{M} \Omega$ ). Neurons were impaled by oscillating the capacitance compensation circuit of a high-input impedance bridge amplifier (Axoclamp 2A). The membrane potential was recorded continuously with a DC-pen recorder. A bipolar hook platinum electrode was used for electrical stimulation of primary afferent nerve fibers in the ipsilateral dorsal root (see Fig. 1A). A second bipolar hook electrode was used in some experiments to record compound action potentials from the dorsal root near the entry zone. The data acquisition and analysis software package "Experimenter's Workbench (Version 4.0)" from Data Wave Technologies was used.

Experimental protocol. Stimulation intensity of dorsal roots was adjusted to yield EPSP amplitudes of 5-15 mV. Pulse width was $0.1 \mathrm{msec}$ unless stated otherwise. Test stimuli were applied at intervals of $60 \mathrm{sec}$. After 10-15 stable responses were recorded, conditioning stimulation was applied, which consisted of 900 pulses given at $1 \mathrm{~Hz}$. These stimulation parameters have been shown to induce LTD in Schaffer collateralCA1 pathway (Dudek and Bear, 1992, 1993). Three different stimulation protocols were used: (1) same stimulation intensity as test stimulation, (2) $10 \mathrm{~V}$ pulses, and (3) $25 \mathrm{~V}, 0.5 \mathrm{msec}$ pulses. In some experiments a second conditioning tetanic stimulus was applied $30 \mathrm{~min}$ after cessation of the $1 \mathrm{~Hz}$ stimulus. Tetanic stimulation consisted of $25 \mathrm{~V}, 0.5 \mathrm{msec}$ pulses given at $100 \mathrm{~Hz}$ for $1 \mathrm{sec}$ three times at $10 \mathrm{sec}$ intervals. To prevent neuronal firing during the course of an experiment and to favor induction of LTD, direct hyperpolarizing current (up to $0.1 \mathrm{nA}$ ) was passed through the recording electrode into the substantia gelatinosa neuron to hold the cell membrane potential negative to the threshold for action potential firing. The active bridge circuit of the preamplifier Axoclamp 2A was used for this purpose. Membrane holding potentials typically ranged between $-75 \mathrm{mV}$ and $-85 \mathrm{mV}$. In any given cell the membrane potential was held within a 1-3 $\mathrm{mV}$ range. Input resistance was measured at $2 \mathrm{~min}$ intervals by passing a hyperpolarizing DC current of $0.05 \mathrm{nA}$ for $200 \mathrm{msec}$.

Data analysis. Individual synaptic responses were digitized at $10 \mathrm{kHz}$ with an analog-to-digital converter card (Data Translation DT 2821) and stored on disk for off-line analysis of EPSP amplitudes, initial slopes, and latencies. Membrane potential and input resistance were determined from each original recording. In addition, the averaged curves of two consecutive synaptic responses were stored and analyzed. The mean amplitude of seven averaged test responses recorded before conditioning stimulation served as controls. Significant changes from controls were assessed by comparing the amplitudes of seven consecutive responses immediately before conditioning stimulation with seven consecutive responses 22-30 min after conditioning stimulation. If not stated otherwise, time courses of depression of EPSP amplitudes were calculated from averaged responses. In some experiments spontaneous or miniature postsynaptic potentials were recorded. This activity was quantified by counting the number of potentials in $5 \mathrm{sec}$ and by measuring the area under the curve of the spontaneous potentials. All values are expressed as mean \pm 1 SEM. Statistical comparisons were made using the nonparametric Wilcoxon rank sum test. Correlations were computed by the Pearson correlation coefficient; $p<0.05$ was considered significant.

Application of drugs. Drugs were added to the superfusion solution at known concentrations. The drugs used were 6-cyano-7-nitroquinoxaline-2,3-dione (CNQX) (10 $\mu \mathrm{M}$; Tocris), D-2-amino-5phosphonovaleric acid (D-APV) $(50 \mu \mathrm{M}$; Cambridge Research Biochemicals), bicuculline methiodide (5 $\mu \mathrm{M}$; Sigma, St. Louis, MO), strychnine (2 $\mu \mathrm{M}$; Sigma), calyculin A (100 nM in $0.1 \%$ DMSO; LC Laboratories). All solutions were freshly prepared every day from stock solutions that were stored at $-20^{\circ} \mathrm{C}$. Free cytosolic $\mathrm{Ca}^{2+}$ in postsynaptic neuron was buffered in some experiments by injecting 1,2-bis(2-aminophenoxy)ethane$N, N, N^{\prime}, N^{\prime}$-tetra-acetic acid (BAPTA, tetrapotassium salt) through the recording electrode. Hyperpolarizing current pulses $(0.1-0.5 \mathrm{nA}, 300$ msec, $1 \mathrm{~Hz}$ ) were given for $10 \mathrm{~min}$. Conditioning stimulation of dorsal roots was given 20-40 min later to ensure diffusion of BAPTA into the dendrites. The same protocol was used in control experiments, except that the recording electrode did not contain BAPTA.

\section{RESULTS}

Results are based on stable intracellular recordings of up to $5 \mathrm{hr}$ obtained from 59 substantia gelatinosa neurons that received fast EPSPs driven by $\mathrm{A} \delta$ - or $\mathrm{C}$-afferent fibers or both. The resting membrane potential of 48 neurons examined was $-70 \pm 2 \mathrm{mV}$ (mean \pm SEM), and the mean amplitude of action potentials was $75 \pm 2 \mathrm{mV}$. Mean input resistance was $185 \pm 12 \mathrm{M} \Omega$, and it did not change significantly after induction of LTD in any of the experimental groups. Under the present experimental conditions, stimulation thresholds for $\mathrm{A} \delta$-fiber volleys in dorsal roots were $2.3 \pm 0.4 \mathrm{~V}(0.1 \mathrm{msec}$ pulses; $n=7)$ and for $\mathrm{C}$-fibers higher than $20 \mathrm{~V}$ with $0.1 \mathrm{msec}$ pulses and $12.0 \pm 1.4 \mathrm{mV}(0.5 \mathrm{msec}$ pulses, $n=$ 4) when the stimulation electrode was placed at the interface between bath solution and air. Thresholds were consistently 1.01.5 V lower when stimulating in oil. Figure $1 C$ illustrates stimulus response functions of $\mathrm{A} \delta$ - and $\mathrm{C}$-fiber volleys in dorsal roots. The intensity of test stimulation of dorsal roots was adjusted between 0.5 and $8 \mathrm{~V}(0.1 \mathrm{msec})$ to typically yield EPSP amplitudes between 5 and $15 \mathrm{mV}$. EPSPs were evoked at latencies between 1.8 and $13.6 \mathrm{msec}$, indicating conduction velocities in afferent nerve fibers between 1 and $10 \mathrm{~m} / \mathrm{sec}$ if central delay is considered to be $1 \mathrm{msec}$. The frequency distribution of conduction velocities in afferent fibers is shown in Figure $1 B$. Purely C-fiber-evoked EPSPs were rarely seen in our experiments, possibly because of the type of slice used. Thus, the description of LTD is based on fast $\mathrm{A} \delta$-fiber-evoked EPSPs.

Monosynaptic EPSPs, which were evoked in $69 \%$ of the neurons, displayed constant latencies and absence of failures during repetitive stimulation of dorsal roots at $20 \mathrm{~Hz}$. The EPSP amplitudes were monotonic functions of the intensity of electrical 

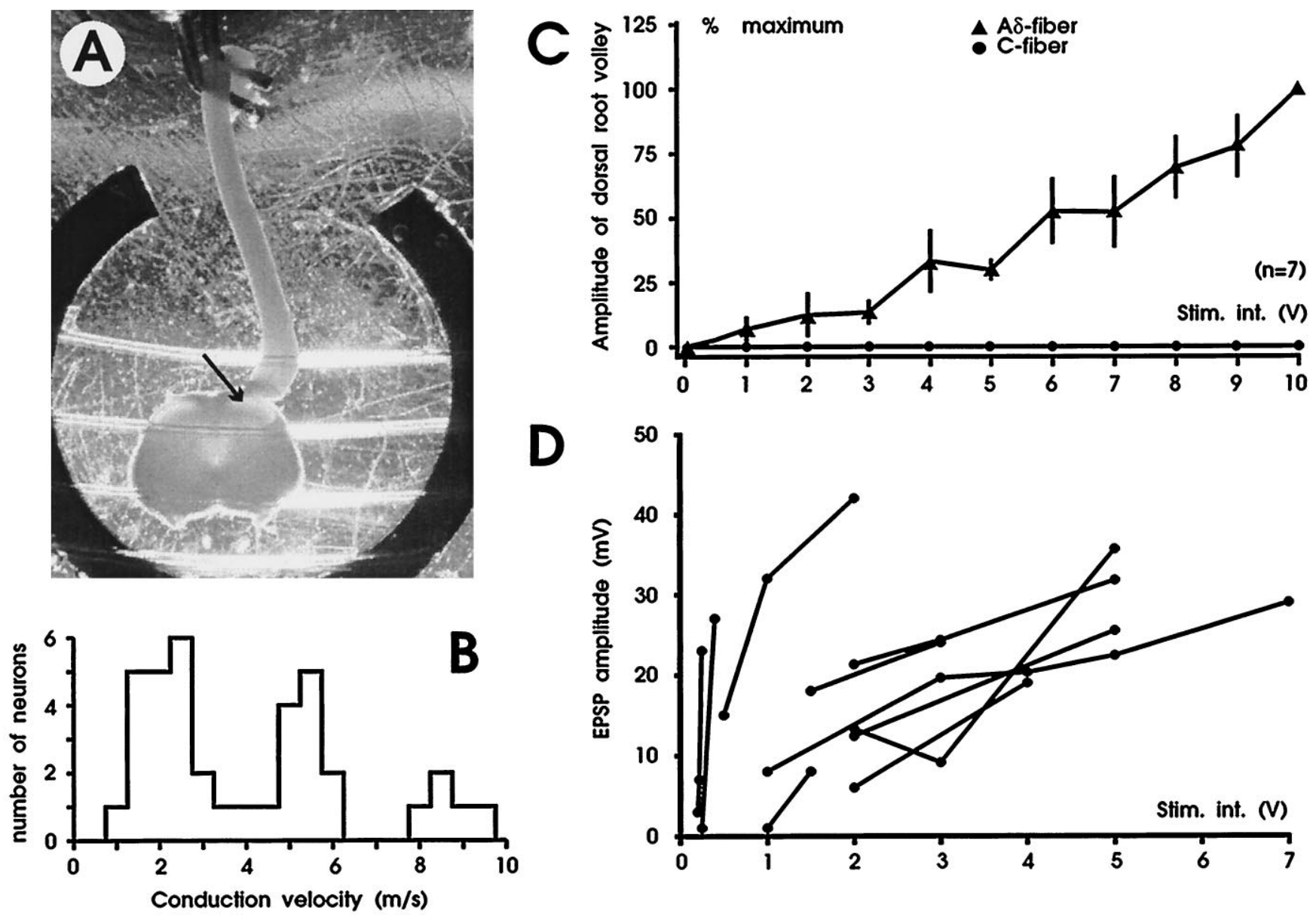

Figure 1. Illustration of some of the characteristics of experimental setup and primary afferent input to substantia gelatinosa neurons. $A$, Photomicrograph shows a transverse spinal cord slice preparation with a long $(\approx 6 \mathrm{~mm})$ dorsal root attached. A bipolar hook electrode is used for electrical stimulation of a dorsal root. The superficial laminae I and II are clearly visible as a translucent band in the dorsal horn (arrow). Inner diameter of ring equals $6.4 \mathrm{~mm}$. $B$, Frequency distribution of conduction velocities of afferent nerve fibers, which evoked the early phase of EPSPs in substantia gelatinosa neurons (bin width is $0.5 \mathrm{~m} / \mathrm{sec} ; n=38$ ). $C$, Compound action potentials in $\mathrm{A} \delta$ - and C-fibers were recorded in dorsal roots in response to stimulation of dorsal roots with $0.1 \mathrm{msec}$ pulses at $1-10 \mathrm{~V}$. Bipolar hook stimulation electrode was placed at the interface between bath solution and air, and recording electrode was in paraffin oil (two-compartment chamber). Near-maximal amplitudes of dorsal root volleys were achieved in A $\delta$-fibers at a stimulation intensity of $10 \mathrm{~V}$. C-fibers were not recruited to a detectable degree at this stimulation intensity. $D$, Individual stimulus-response functions from 10 different substantia gelatinosa neurons are shown. EPSP amplitudes were monotonic functions of the stimulation intensity of the dorsal root (0.1 msec pulses).

dorsal root stimulation. Individual stimulus response functions are shown in Figure $1 D$. Steep stimulus response functions suggest that these neurons have input from a rather homogeneous population of afferent nerve fibers with similar electrical thresholds for activation. In agreement with previous reports (Yoshimura and Jessell, 1990; Randić et al., 1993; Barnes-Davies and Forsythe, 1995), blockade of NMDA receptors with D-APV (50 $\mu \mathrm{M})$ slightly reduced EPSP amplitudes and reduced the duration of the EPSPs (data not shown). Additional blockade of AMPA/ kainate receptors with CNQX $(10 \mu \mathrm{M})$ always abolished EPSPs (data not shown). Thus, EPSPs were generated by glutamategated conductances, mainly of the non-NMDA type. To favor induction of LTD, postsynaptic neurons were hyperpolarized (Artola et al., 1990; Randić et al., 1993) (typically to $-75 \mathrm{mV}$ to $-85 \mathrm{mV})$. These hyperpolarizing currents were small (0.01-0.1 $\mathrm{nA}$ ) and did not affect EPSP amplitudes qualitatively. Maximal EPSP amplitudes increased by up to $10 \%$ at more negative membrane potentials.

\section{LTD of synaptic efficiency by $1 \mathrm{~Hz}$ stimulation of A $\delta$ - fibers in dorsal roots}

To test whether LTD can be induced at the synapses between primary afferent fibers and substantia gelatinosa neurons, we stimulated dorsal roots at $1 \mathrm{~Hz}$ for $15 \mathrm{~min}$. In eight experiments the intensity of conditioning stimulation was identical to the intensity of test stimulation $(0.5-8.0 \mathrm{~V})$. Five minutes after cessation of conditioning stimulation, EPSP amplitudes of all eight neurons tested were depressed to a mean of $57 \pm 13 \%$ of control. There was usually a considerable recovery in response within 30 min (to $88 \pm 10 \%$ of control) (Fig. 2). Thus, short-term depression but not LTD was induced. To test whether cooperativity between afferent $\mathrm{A} \delta$-fibers is required to induce LTD, the intensity of conditioning stimulation was raised to $10 \mathrm{~V}$. At this stimulation intensity almost all A $\delta$-fibers but only a few or no $\mathrm{C}$-fibers are recruited (Fig. $1 C$ ). These stimulation parameters produced a robust LTD that remained throughout the duration of the recording (30-160 min) in all eight neurons tested (Fig. 3). 

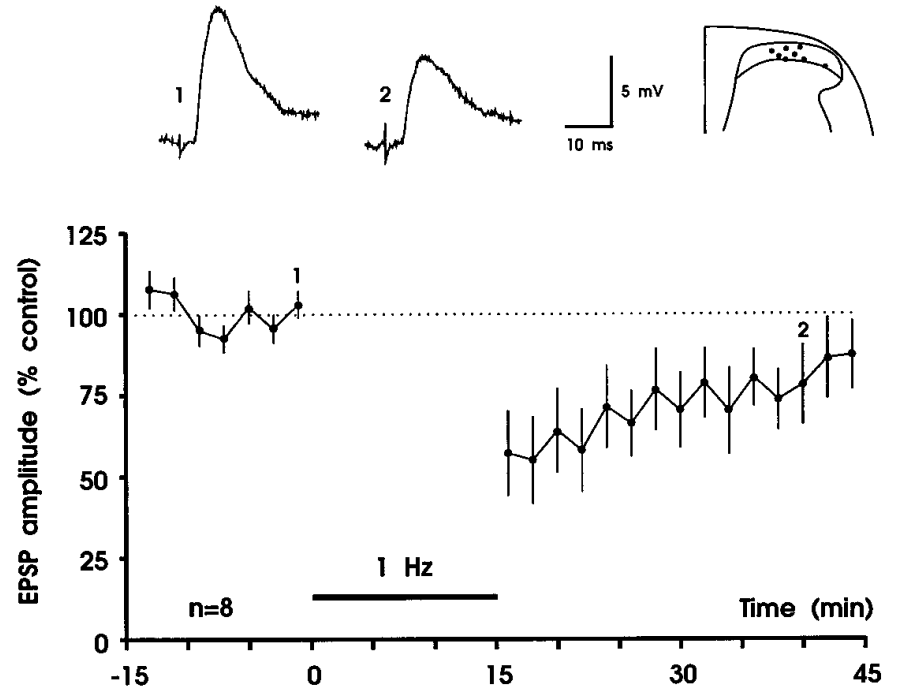

Figure 2. Short-term depression of fast excitatory synaptic transmission in the superficial spinal dorsal horn. In each experiment EPSPs were evoked by electrical stimulation of a dorsal root at $60 \mathrm{sec}$ intervals, and two consecutive EPSPs were averaged. Each data point represents the mean EPSP amplitude of eight different substantia gelatinosa neurons. Responses were normalized to the EPSP amplitudes recorded before conditioning stimulation (controls). Conditioning stimulation consisted of 900 pulses given at $1 \mathrm{~Hz}$ (black horizontal bar). Intensity of conditioning stimulation was identical to test stimulation intensity $(0.5-8 \mathrm{~V}, 0.1 \mathrm{msec})$. This stimulation paradigm produced a short-term depression of synaptic transmission. Original (not averaged), apparently monosynaptic EPSPs that were recorded immediately before conditioning stimulation (trace 1) and at time $40 \mathrm{~min}$ (trace 2) of one of the neurons are shown above the graph. Visually identified recording sites are superimposed on a representative section through the lumbar spinal cord. $V_{\mathrm{m}}=-68$ to $-85 \mathrm{mV}$; 22- to 27 -d-old rats.

Thirty minutes after conditioning stimulation, maximal amplitudes of EPSPs of all neurons were depressed to $41 \pm 10 \%$ of control (Fig. 3B) and initial slopes of EPSPs were depressed to $43 \pm 13 \%$ of control. Amplitudes of monosynaptic EPSPs were depressed to $39 \pm 17 \%$ of control $(n=4)$, and amplitudes of polysynaptic EPSPs were depressed to a similar degree (to $43 \pm$ $9 \% ; n=4)$. The number of spontaneous excitatory postsynaptic potentials was counted for each of the eight neurons examined during a $5 \mathrm{sec}$ interval and was not different before $(13 \pm 2)$ and 20-30 min after conditioning $1 \mathrm{~Hz}$ stimulation $(14 \pm 3)$. The size of spontaneous EPSPs was determined as area under the curve and was not statistically different before and 20-30 min after (to $84 \pm 24 \%$ of control) conditioning stimulation (Wilcoxon signed rank sum test; $n=8$ ). When a constant holding current was used, membrane potential was not affected by conditioning stimulation $(-83 \pm 1 \mathrm{mV}$ before and $-82 \pm 1 \mathrm{mV} 30 \mathrm{~min}$ after $1 \mathrm{~Hz}$ stimulation). Within the given range of membrane potentials (typically -75 to $-85 \mathrm{mV}$, in a few neurons up to $-94 \mathrm{mV}$ ), LTD was equally effective; thus magnitude of LTD was not correlated with $V_{\mathrm{m}}\left(r_{\mathrm{s}}=-0.108 ; p>0.05\right)$.

To test whether additional recruitment of C-fibers during conditioning stimulation further depresses synaptic responses, stimulation parameters of $25 \mathrm{~V}$ and $0.5 \mathrm{msec}$ were used. In three neurons that received both $\mathrm{A} \delta$ - and $\mathrm{C}$-fiber input from the dorsal roots, the time course of depression was not significantly different when compared with conditioning stimulation of A-fibers alone (Fig. 4). Thus, cooperativity of C-fibers is not required for maximal expression of LTD. Consequently $1 \mathrm{~Hz}$ stimulation with 10 $\mathrm{V}, 0.1 \mathrm{msec}$ pulses was used in all subsequent experiments.
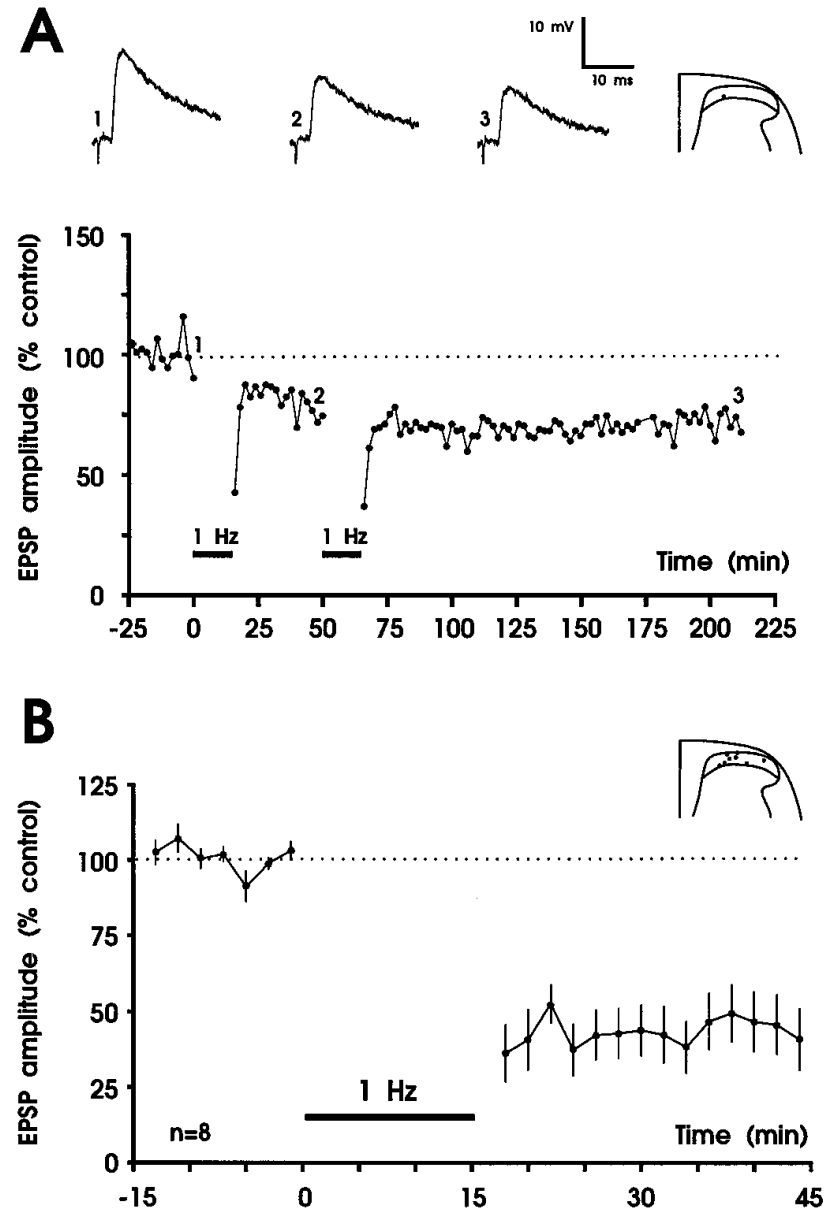

Figure 3. Robust LTD of fast excitatory synaptic transmission in the superficial spinal dorsal horn by low-frequency stimulation of primary afferent A $\delta$-fibers. $A$, Results from one experiment. Amplitudes from averaged EPSPs are plotted versus time. Representative original recordings of apparently monosynaptic EPSPs and the recording site in substantia gelatinosa are shown in the inset. In this experiment LTD was weak, and a second conditioning stimulus was applied that only slightly increased the strength of LTD. Thus, the first conditioning stimulus almost saturated LTD, which lasted throughout the recording period. The mean time course of inhibition and the recording sites of all eight experiments are shown in $B . A, V_{\mathrm{m}}=-85 \mathrm{mV}, 21$-d-old rat; $B, V_{\mathrm{m}}=-78$ to $-88 \mathrm{mV}$, 19- to 23 -d-old rats.

\section{Activation of $\mathrm{GABA}_{\mathrm{A}}$ or glycine receptors is not required for induction of $L T D$}

In accordance with a previous report (Yoshimura and Nishi, 1995), we found a strong tonic inhibition of evoked and spontaneous EPSPs in substantia gelatinosa neurons via $\mathrm{GABA}_{\mathrm{A}}$ and/or glycine receptors. When the $\mathrm{GABA}_{\mathrm{A}}$ receptor antagonist bicuculline $(5 \mu \mathrm{M})$ and the glycine receptor antagonist strychnine (2 $\mu \mathrm{M})$ were added to the bath solution, presumed, monosynaptically evoked EPSPs were increased, both in amplitude and duration (the latter up to $3 \mathrm{sec}$ ). In addition, polysynaptic and/or spontaneous EPSPs were superimposed on evoked EPSPs (data not shown). Pharmacological blockade of $\mathrm{GABA}_{\mathrm{A}}$ and glycine receptors had no discernible effect on the ability of slices to generate LTD of the similar magnitude (to $53 \pm 8 \%$ of control) seen in the slices perfused with control solution (Fig. 5, Table 1). Thus, neither $\mathrm{GABA}_{\mathrm{A}}$ nor glycine receptors are required for induction or maintenance of LTD in superficial spinal dorsal horn by $1 \mathrm{~Hz}$ stimulation of dorsal roots. 


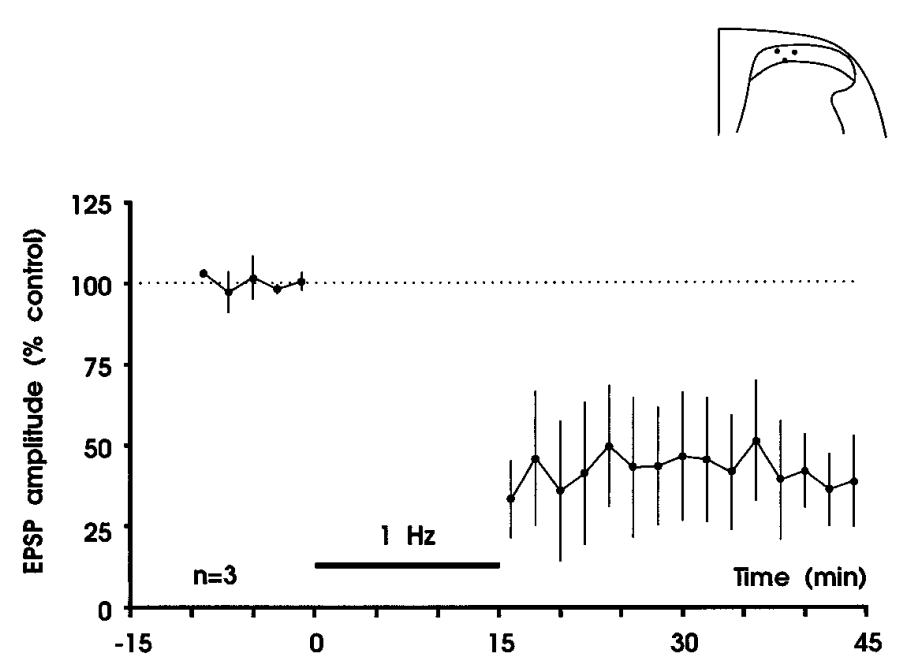

Figure 4. Conditioning low-frequency stimulation of A- and C-fibers in dorsal roots is as effective as A-fiber stimulation alone. Mean time course ( \pm SEM) of inhibition induced by $1 \mathrm{~Hz}$ stimulation at $25 \mathrm{~V}, 0.5 \mathrm{msec}$ of the three neurons tested is shown. The recording sites in the superficial spinal dorsal horn are shown above the graph. $V_{\mathrm{m}}=-73$ to $-76 \mathrm{mV} ; 18$ - to 26-d-old rats.

\section{Blockade of induction of LTD by NMDA receptor antagonist D-APV}

NMDA receptor blockade by adding D-APV $(50 \mu \mathrm{M})$ to the bath solution throughout the recording period abolished or strongly reduced the induction of LTD in 8 of 11 neurons tested (Wilcoxon signed rank sum test; $p<0.05$ ). In the same experiments high-frequency, high-intensity stimulation had no effect on EPSP amplitude (Fig. 6A, Table 2). In three experiments D-APV was washed out for 40-50 min and then a second $1 \mathrm{~Hz}$ conditioning stimulus was applied. Induction of LTD was blocked in the presence of D-APV (responses were to $96 \pm 8 \%$ of control) but recovered at least partially after wash-out (depression to $71 \pm 4 \%$ of control). These data suggest a possible involvement of NMDA receptors in the induction mechanisms of LTD.

\section{Buffering postsynaptic $\mathrm{Ca}^{2+}$ with BAPTA attenuates LTD}

Because NMDA receptor-dependent LTD in hippocampus requires a rise in postsynaptic $\mathrm{Ca}^{2+}$ (Dudek and Bear, 1992; Mulkey and Malenka, 1992), an obvious question is whether presently described LTD could also be blocked by buffering postsynaptic $\mathrm{Ca}^{2+}$. In four experiments the $\mathrm{Ca}^{2+}$ chelator BAPTA was added to the pipette solution (100-200 $\mathrm{mm}$ ) and injected into the postsynaptic cell using hyperpolarizing current pulses (see Materials and Methods). BAPTA blocked induction of LTD by conditioning $1 \mathrm{~Hz}$ stimulation in one cell (EPSP amplitude was to $111 \%$ of control $30 \mathrm{~min}$ after stimulation) and attenuated LTD in three other cells (mean depression to $70 \pm 8 \%$ control) (Fig. 7). In two control experiments LTD was induced to 82 and $16 \%$ of control, respectively.

\section{The role of protein phosphatases 1 and $2 \mathrm{~A}$ in induction of LTD in spinal cord}

It has been suggested that the level of phosphorylation of some phosphoproteins determines the magnitude of synaptic responses and that LTP may result from activation of protein kinases and LTD from activation of protein phosphatases (Lisman, 1989, 1994; Malenka et al., 1989; Mulkey et al., 1993). To test whether LTD by $1 \mathrm{~Hz}$ stimulation of dorsal roots involves protein phos-
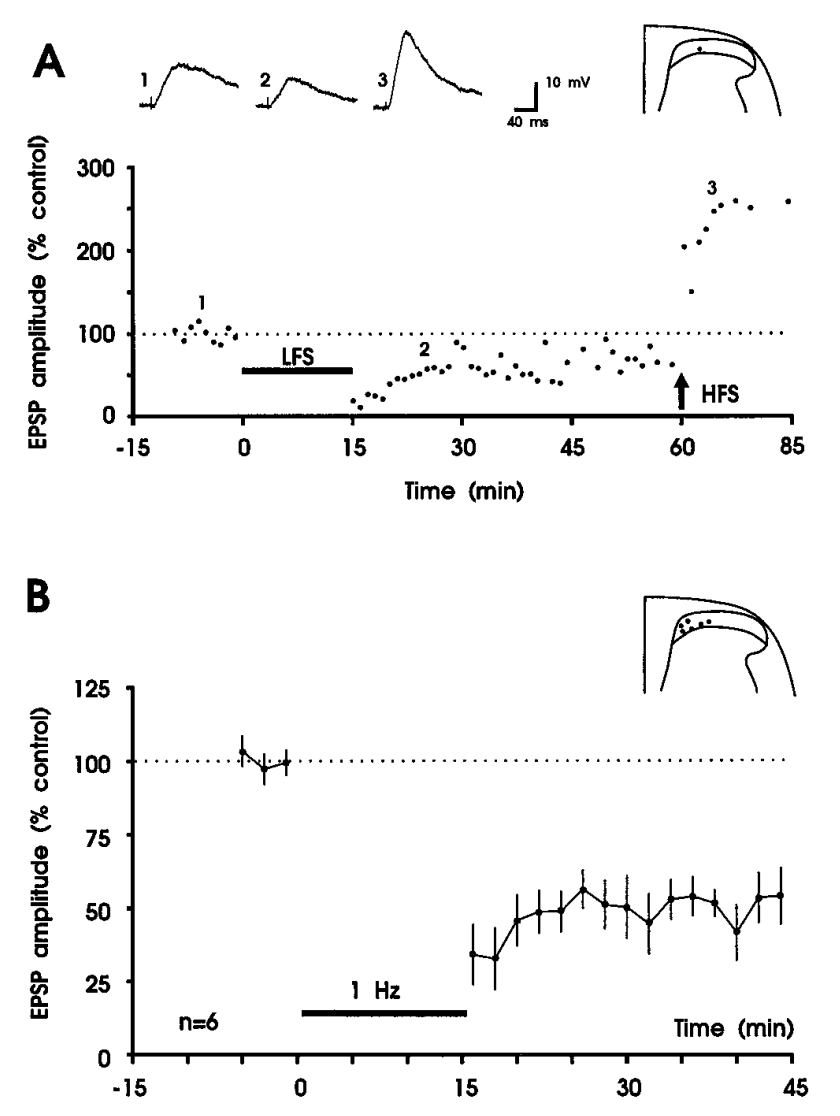

Figure 5. Bicuculline $(5 \mu \mathrm{M})$ and strychnine $(2 \mu \mathrm{M})$ in superfusate do not affect LTD. $A$, LTD and LTP can be elicited in the same neuron during blockade of $\mathrm{GABA}_{\mathrm{A}}$ and glycine receptors. Results from one experiment are shown. In the graph, each data point represents the maximal amplitude of one original EPSP recorded before and after conditioning $1 \mathrm{~Hz}$ stimulation (horizontal bar, LFS, $10 \mathrm{~V}, 0.1 \mathrm{msec}$ ) and conditioning high frequency tetanic stimulation (arrow, HFS, $100 \mathrm{~Hz}, 25 \mathrm{~V}, 0.5 \mathrm{msec}$; given three times for $1 \mathrm{sec}$ at $10 \mathrm{sec}$ intervals). Averaged polysynaptic EPSPs before (trace 1) and after $1 \mathrm{~Hz}$ stimulation (trace 2) and after tetanic stimulation (trace 3) and the recording site are shown above the graph. Variability in EPSP amplitude measurements is attributable, in part, to the superposition of spontaneous EPSPs. $V_{\mathrm{m}}=-85 \mathrm{mV}$; 22-d-old rat. $B$, Summary of the effects of $\mathrm{GABA}_{\mathrm{A}}$ and glycine receptor blockade on induction of LTD in six neurons of superficial spinal dorsal horn. The mean time course of averaged EPSP amplitudes before and after conditioning $1 \mathrm{~Hz}$ stimulation $(10 \mathrm{~V}, 0.1 \mathrm{msec})$ is shown. The recording sites are shown in the inset. $V_{\mathrm{m}}=-74$ to $-85 \mathrm{mV} ; 21$ - to 26 -d-old rats.

phatases 1 and $2 \mathrm{~A}$, experiments were conducted in the presence of calyculin A, a potent selective and membrane-permeable inhibitor of protein phosphatases 1 and $2 \mathrm{~A}$. In the presence of calyculin A, LTD was to $15 \pm 6 \%$ of control (100 nM; $n=4)$ (Fig. 8). Table 1 summarizes the effects of conditioning $1 \mathrm{~Hz}$ stimulation on EPSP amplitudes of slices in a control medium, under conditions of pharmacological blockade of synaptic inhibition and blockade of protein phosphatases 1 and $2 \mathrm{~A}$ by calyculin $\mathrm{A}$.

\section{High-frequency, high-intensity stimulation reverses LTD}

To eliminate the possibility that LTD may reflect excitotoxicity at individual synapses rather than a true decrease in synaptic efficacy, we examined whether the depressed input could still undergo LTP after a high-frequency tetanus. In three neurons, tetanic stimulation produced LTP (Fig. $5 A$ ); in three other neurons tetanic stimulation reversed LTD, and in one additional 
Table 1. Summary of the effects of conditioning $1 \mathrm{~Hz}$ stimulation on EPSP amplitudes in slices that were superfused with normal Krebs or with solutions that contained bicuculline $(5 \mu \mathrm{M})$ and strychnine $(2 \mu \mathrm{M})$ (BIC/STRY), D-APV (50 $\mu \mathrm{M})$, or calyculin A (100 nM)

Bath/pipette solution

\begin{tabular}{|c|c|c|c|c|c|c|c|c|}
\hline & \multicolumn{8}{|c|}{ solution } \\
\hline & ACSF & & & BIC/STRY & D-APV & Calyculin A & Calyculin A & BAPTA \\
\hline Concentration $(\mu \mathrm{M})$ & & & & $5 / 2$ & 50 & 0.1 & 0.5 & \\
\hline Stimulation intensity $(\mathrm{V})$ & $0.5-8.0$ & 10 & 25 & 10 & 10 & 10 & 10 & 10 \\
\hline EPSP amplitude (\% control) & $88 \pm 10$ & $41 \pm 10^{*}$ & $39 \pm 14^{*}$ & $53 \pm 8^{*}$ & $92 \pm 9$ & $15 \pm 6^{*}$ & $42 \pm 9^{*}$ & $80 \pm 11^{*}$ \\
\hline Number of neurons tested & 8 & 8 & 3 & 6 & 11 & 4 & 3 & 4 \\
\hline
\end{tabular}

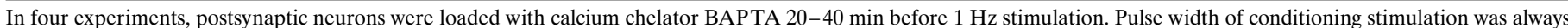

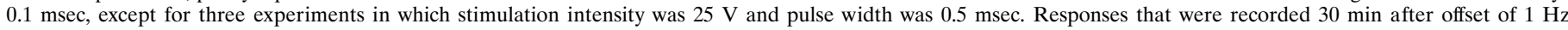
stimulation are expressed as percent of control responses.

* Significantly lower than control response $(p \leq 0.05)$.

neuron LTD was significantly reduced. This observation does not rule out presynaptic damage or neurotransmitter depletion of the conditioning primary afferent pathway, but it does mean that the depressed synapses are sufficiently viable to support the mechanisms underlying LTP (Dudek and Bear, 1992).

\section{Habituation of EPSP amplitudes during $1 \mathrm{~Hz}$ stimulation}

To evaluate the immediate impact of $1 \mathrm{~Hz}$ stimulation $(10 \mathrm{~V}, 0.1$ msec pulses) on A $\delta$-fiber-evoked EPSP amplitudes, responses were normalized to the EPSP evoked by the first stimulus of the $1 \mathrm{~Hz}$ train. Figure 9 illustrates the time courses of EPSP amplitudes during $1 \mathrm{~Hz}$ stimulation. When NMDA receptors were blocked by bath application of D-APV $(50 \mu \mathrm{M})$, the time course of inhibition was similar to that in control experiments (Fig. 9C). Thus, habituation during $1 \mathrm{~Hz}$ stimulation, unlike LTD, does not require activation of NMDA receptors. When $\mathrm{GABA}_{\mathrm{A}}$ and glycine receptors were blocked by bicuculline and strychnine, the time course of habituation was different as compared with controls (Fig. 9D). During blockade of protein phosphatases 1 and $2 \mathrm{~A}$ by bath application of calyculin A (100 nM), habituation during $1 \mathrm{~Hz}$ stimulation seemed to be even stronger than under control conditions (Fig. 9E). The mechanisms underlying these differences in habituation are presently unknown.

\section{Paired-pulse depression of monosynaptically A $\delta$-fiber-evoked EPSPs}

In nine neurons, monosynaptic EPSPs were evoked by paired pulses at $50 \mathrm{msec}$ intervals. In seven neurons, mean amplitude of the second EPSP was significantly reduced to $64 \pm 12 \%$ of the amplitude of the first EPSP. In two other neurons, the amplitude of the second EPSP did not change $(101 \%)$ or was enhanced $(138 \%)$. The paired-pulse depression of monosynaptic EPSPs was not abolished by NMDA receptor blockade during bath application of 50 $\mu \mathrm{M}$ D-APV (depression to $72 \pm 3 \%$ ) in seven neurons tested. Paired-pulse depression was unaffected (depression to $65 \pm 9 \%$; $n=5)$ by bath application of bicuculline $(5 \mu \mathrm{M})$ and strychnine $(2$ $\mu \mathrm{M})$. Pinco and Lev-Tov (1993) have also described a marked depression of monosynaptic EPSPs of $\alpha$-motoneurons during 5-10 $\mathrm{Hz}$ stimulation of dorsal roots and a paired-pulse depression at interstimulus intervals ranging from $15 \mathrm{msec}$ to $5 \mathrm{sec}$.

\section{DISCUSSION}

The present study describes a new form of LTD of excitatory synaptic transmission in substantia gelatinosa neurons from the rat spinal dorsal horn that can be induced by conditioning lowfrequency stimulation of primary afferent $\mathrm{A} \delta$-fibers.

\section{Cooperativity of afferent $\mathbf{A} \boldsymbol{\delta}$-fibers is required for induction of LTD}

Low-frequency conditioning stimulation at test stimulation intensity induced a short-term depression, suggesting that the same synapses that are active during test stimulation are not sufficient to trigger the cellular events that are required for induction of LTD. In hippocampus and other areas of the brain, LTD is characterized by the phenomenon of cooperativity, i.e., the need to recruit a critical number of afferents during conditioning stimulation (Linden, 1994). Here, conditioning stimulation of almost all afferent $\mathrm{A} \delta$-fibers was as effective as conditioning stimulation of all afferent nerve fibers in a dorsal root including afferent $\mathrm{C}$-fibers. It seems, therefore, that the cooperativity of $\mathrm{A} \delta$-fibers but not afferent C-fibers is necessary to induce an LTD.

\section{Role of inhibitory neurotransmission for LTD in spinal dorsal horn}

The two major inhibitory neurotransmitters in spinal cord including substantia gelatinosa are GABA acting on $\mathrm{GABA}_{\mathrm{A}}$ and $\mathrm{GABA}_{\mathrm{B}}$ receptors and glycine acting on glycine receptors or on glycine-binding sites of the NMDA receptor. Low-frequency stimulation $(0.5-5.0 \mathrm{~Hz})$ of afferent nerve fibers may favor presynaptic GABAergic inhibition in spinal dorsal horn (Polc and Ducic, 1990). In the presently used transverse slice preparation of the spinal cord, tonic release of GABA and/or glycine has profound effects on sculpturing EPSPs: amplitude and duration of EPSPs strongly increased during receptor blockade. To test the possibility that LTD is not a homosynaptic depression but rather a buildup of inhibition, we have blocked $\mathrm{GABA}_{\mathrm{A}}$ and glycine receptors simultaneously. This did not change the efficacy of conditioning low-frequency stimulation excluding any crucial role of these receptors for spinal LTD. Thus, LTD of neurotransmission in $\mathrm{A} \delta$-fibers may involve different cellular and synaptic mechanisms as compared with A-fiber-induced inhibition of C-fiberevoked responses in spinal dorsal horn, which has been proposed to involve presynaptic inhibition via inhibitory, possibly GABAergic, interneurons (Melzack and Wall, 1965). Recent evidence suggests that activation of $\mu$-opiate receptor activation is required for induction of LTD in spinal cord substantia gelatinosa (J. Zhong and M. Randić, unpublished observations).

\section{Activation of NMDA receptors is required for induction of spinal LTD by low-frequency stimulation}

The same pattern of conditioning stimulation may induce LTP or LTD, depending on the level of postsynaptic depolarization (Artola et al., 1990; Randić et al., 1993). We have shown previously that conditioning stimulation of dorsal roots with high-frequency 
A
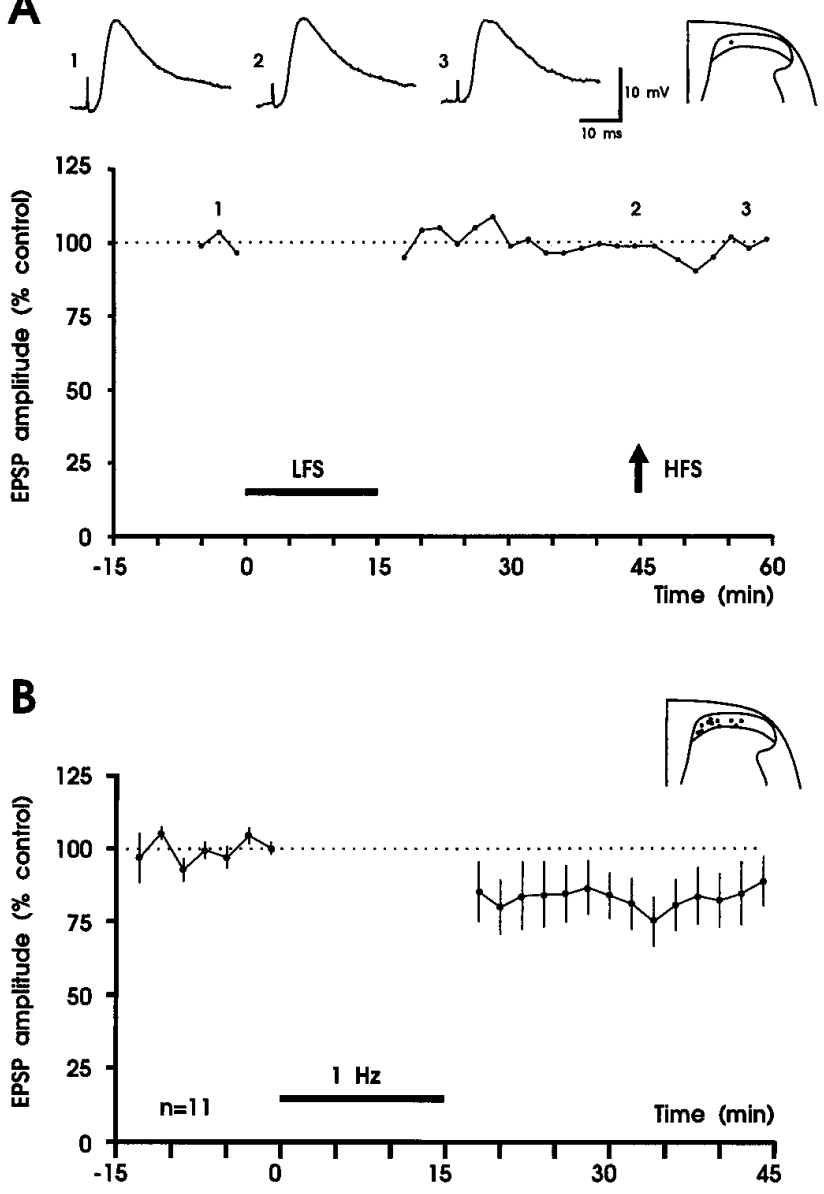

Figure 6. NMDA receptor antagonist D-APV affects induction of LTD and LTP in superficial spinal dorsal horn. $A$, Results from one experiment. Amplitudes of averaged EPSPs are plotted versus time before and after conditioning $1 \mathrm{~Hz}$ stimulation (black horizontal bar, LFS, $10 \mathrm{~V}, 0.1 \mathrm{msec}$ ) and high-frequency tetanic stimulation (arrow, $H F S, 100 \mathrm{~Hz}, 25 \mathrm{~V}, 0.5 \mathrm{msec}$; given three times for $1 \mathrm{sec}$ at $10 \mathrm{sec}$ intervals). Original recordings of apparently monosynaptic EPSPs and the recording site are shown above the graph. The summary of the results is shown in $B$. In the presence of D-APV $(50 \mu \mathrm{M})$, conditioning $1 \mathrm{~Hz}$ stimulation fails to induce robust LTD in 11 neurons tested. Recording sites are shown in the inset. $A, V_{\mathrm{m}}=-78 \mathrm{mV}$, 21-d-old rat; $B, V_{\mathrm{m}}=-74$ to $-94 \mathrm{mV}, 18$ - to 23 -d-old rats.

bursts $(100 \mathrm{~Hz})$ may produce LTP when the postsynaptic spinal dorsal horn neuron is depolarized to approximately $-70 \mathrm{mV}$. The same conditioning stimulation, however, may evoke LTD when the same neuron is hyperpolarized to approximately -85 $\mathrm{mV}$ (Randić et al., 1993). To favor induction of LTD in the present study, neurons were hyperpolarized to approximately $-85 \mathrm{mV}$ by injecting negative current.

A voltage-dependent threshold mechanism may exist in the postsynaptic neuron that determines the direction of synaptic gain change (Artola et al., 1990). It is believed that both LTP and LTD at synapses in various brain regions require elevation of free cytosolic $\mathrm{Ca}^{2+}$ concentrations via activation of NMDA receptors (Lisman, 1989; Bliss and Collingridge, 1993; Linden, 1994; Singer, 1995). The absolute level of $\left[\mathrm{Ca}^{2+}\right]_{\mathrm{i}}$ would determine whether synaptic efficiency increases (large elevation of $\left[\mathrm{Ca}^{2+}\right]_{\mathrm{i}}$ ) or declines (moderate to small increases in $\left[\mathrm{Ca}^{2+}\right]_{\mathrm{i}}$ ) (Lisman, 1989; Neveu and Zucker, 1996). The absolute value of $\left[\mathrm{Ca}^{2+}\right]_{\mathrm{i}}$ may differentially affect activity of some phosphoprotein kinases (which may have high $K_{\mathrm{D}}$ ) and some protein phosphatases [with
Table 2. Summary of the effect of a second conditioning high-frequency stimulus (HFS) on EPSP amplitudes

\begin{tabular}{lllll} 
& \multicolumn{2}{l}{ Bath solution } \\
\cline { 2 - 5 } & \multicolumn{2}{l}{ BIC/STRY } & D-APV \\
\hline Conditioning stimulation & 1. LFS & 2. HFS & 1. LFS & 2. HFS \\
EPSP amplitude (\% control) & $47 \pm 10^{*}$ & $103 \pm 12$ & $86 \pm 13$ & $97 \pm 16$ \\
Number of neurons tested & 5 & 5 & 7 & 7
\end{tabular}

Slices were superfused with a solution that contained either bicuculline $(5 \mu \mathrm{M})$ and strychnine $(2 \mu \mathrm{M})(\mathrm{BIC} / \mathrm{STRY})$ or D-APV $(50 \mu \mathrm{M})$. Responses recorded $30 \mathrm{~min}$ after the first conditioning low-frequency stimulus (1. LFS) and $15 \mathrm{~min}$ after the second conditioning stimulus (2. HFS) are expressed as percent of control responses.

* Significantly different from control $(p \leq 0.05)$.

$K_{\mathrm{D}}$ values two to three orders of magnitude lower than those for kinase activation (Lisman, 1989, 1994)], which might lead to LTD and LTP, respectively.

NMDA-insensitive forms of LTD or LTP have been described and may involve $\left[\mathrm{Ca}^{2+}\right]_{\mathrm{i}}$ increases via $\mathrm{Ca}^{2+}$ influx through voltage-sensitive $\mathrm{Ca}^{2+}$ channels (Linden, 1994) or $\mathrm{Ca}^{2+}$ release from intracellular stores via phospholipase $\mathrm{C}-\mathrm{IP}_{3}$ pathway (Johnston et al., 1992). Here, blockade of NMDA receptors by bath application of D-APV abolished or reduced LTD by lowfrequency stimulation of afferent $\mathrm{A} \delta$-fibers in most neurons tested. Similar results were obtained when spinal LTD was induced by brief, high-frequency stimulation of dorsal roots (G. Cheng, J. Sandkühler, and M. Randić, unpublished observations). In contrast, habituation of EPSPs during conditioning $1 \mathrm{~Hz}$ stimulation was independent of NMDA receptor activation in the present study, indicating that the underlying mechanisms are different.

NMDA receptors are present postsynaptically, and the existence of presynaptic NMDA receptors in spinal cord dorsal horn has been suggested (Liu et al., 1994). Thus, our results may not allow firm conclusions about the pre- or postsynaptic nature of the induction mechanism. Preliminary evidence suggests that buffering $\mathrm{Ca}^{2+}$ in the postsynaptic neuron may reduce, albeit not
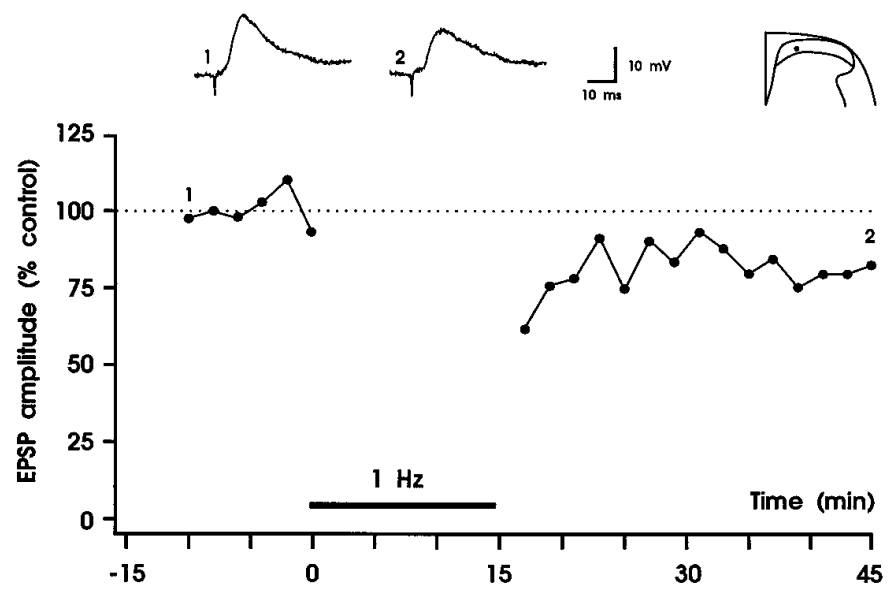

Figure 7. Buffering postsynaptic $\mathrm{Ca}^{2+}$ attenuates LTD by low-frequency stimulation. Results from a neuron that was loaded with BAPTA 40 min before onset of conditioning $1 \mathrm{~Hz}$ stimulation $(10 \mathrm{~V}, 0.1 \mathrm{msec}$; horizontal bar) are shown. Amplitudes of averaged EPSPs are plotted versus time. Responses were depressed to $79 \%$ of control 30 min after offset of $1 \mathrm{~Hz}$ stimulation. Original recordings of apparently monosynaptic EPSPs before (trace 1) and after (trace 2) $1 \mathrm{~Hz}$ stimulation are shown above the graph. $V_{\mathrm{m}}=-92 \mathrm{mV} ; 19$-d-old rat. 


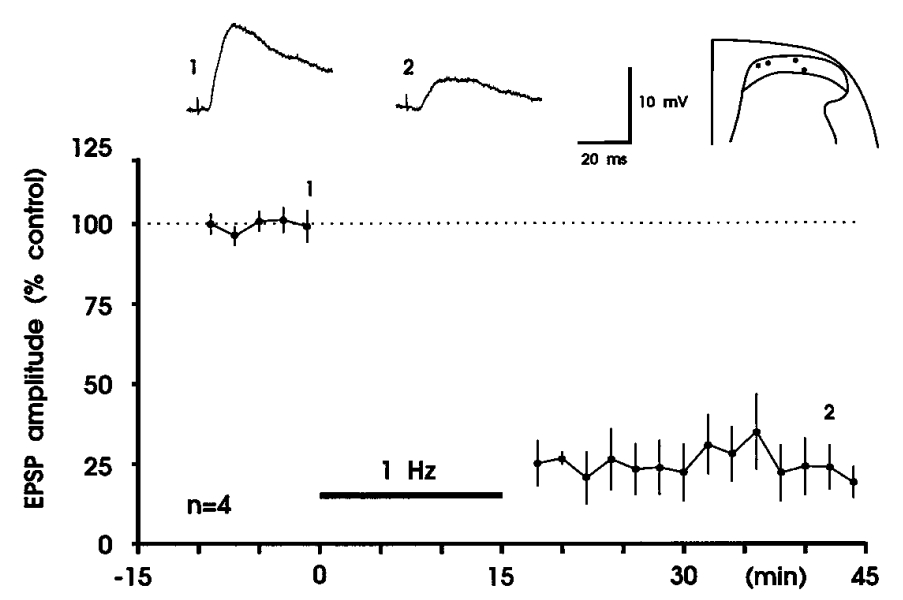

Figure 8. Phosphatase inhibitor calyculin A does not block induction of LTD by low-frequency stimulation of dorsal roots. Figure shows summary of the results of four experiments in which calyculin A was added to the superfusion solution at a concentration of $100 \mathrm{nM}$. Slices were incubated for 1-3 hr with calyculin A before conditioning $1 \mathrm{~Hz}$ stimulation $(10 \mathrm{~V}, 0.1$ msec) was begun. Original polysynaptic EPSP recordings of one of the neurons before (trace 1) and after (trace 2) conditioning stimulation and the recording sites are shown above the graph. Mean EPSP amplitudes of four neurons $( \pm \mathrm{SEM})$ are plotted versus time. $V_{\mathrm{m}}=-81$ to $-85 \mathrm{mV} ; 19$ or 20 -d-old rats.

reliably block, induction of LTD by low-frequency stimulation (1 $\mathrm{Hz}$ ). Our recent data show that buffering postsynaptic $\mathrm{Ca}^{2+}$ by BAPTA consistently and markedly reduced LTD by highfrequency stimulation (100 Hz) (G. Cheng, J. Sandkühler, and M. Randić, unpublished observations), suggesting that the relative importance of calcium-dependent processes in the postsynaptic neuron may be different in these two forms of spinal LTD. This conclusion is in line with the differential effect of the phosphatase inhibitor calyculin A, which blocked LTD by high-frequency stimulation (G. Cheng, J. Sandkühler, and M. Randić, unpublished observations) but failed to attenuate LTD by lowfrequency stimulation in the present study. Thus, different patterns of conditioning afferent stimulation may activate two distinct forms of spinal LTD: low frequency LTD, which in part appears to be independent of rise in postsynaptic $\mathrm{Ca}^{2+}$ and does not require activation of protein phosphatase 1 or protein phosphatase $2 \mathrm{~A}$, and high frequency LTD, which requires both rise in postsynaptic $\mathrm{Ca}^{2+}$ and activation of these phosphatases.

\section{Possible biological function of LTD by low-frequency afferent stimulation}

Continuous or repetitive stimulation often leads to reduced responses in sensory systems. This may include mechanisms such as adaptation, habituation, receptor desensitization or internalization, recurrent or feedback inhibition, or inhibition of neurotransmitter release by activation of autoreceptors. Some of these mechanisms are reversible within a few milliseconds to seconds. The presently described LTD of primary afferent neurotransmission may involve other mechanisms or may be the consequence of one of the above mentioned changes, e.g., a prolonged desensitization of postsynaptic receptors (Linden, 1994) or a decrease in neurotransmitter release. In any case, this LTD may effectively prevent buildup of excitation in repetitively stimulated pathways.

Possibly, this LTD may be involved in long-lasting therapeutic effects of counterstimulation (Chung et al., 1983, 1984) such as electroacupuncture at low-stimulation frequencies, which is often

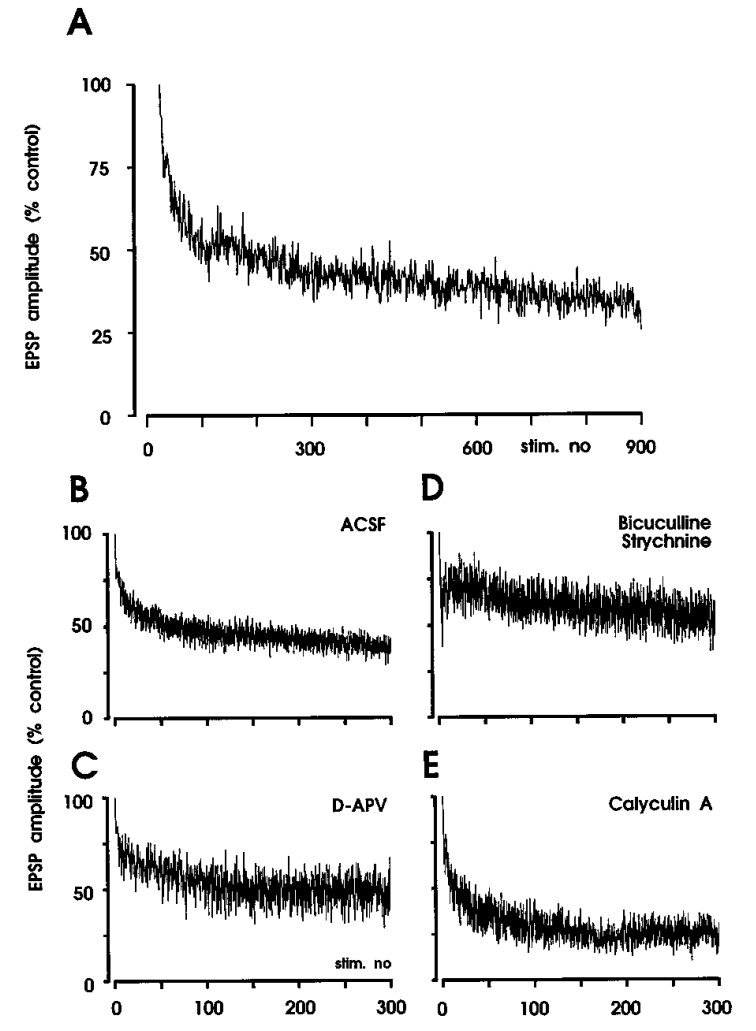

Figure 9. Habituation of EPSP amplitudes during $1 \mathrm{~Hz}$ stimulation. $A$, The graph shows the time course of habituation of EPSP amplitudes in one neuron during stimulation of dorsal root at $1 \mathrm{~Hz}$. Amplitudes of original EPSPs are normalized to the amplitude of the first response and were connected by straight lines. Summary of the results during superfusion with artificial cerebrospinal fluid $(A C S F ; n=7)$, bicuculline $(5 \mu \mathrm{M})$ and strychnine $(2 \mu \mathrm{M} ; n=3)$, D-APV $(50 \mu \mathrm{M} ; n=6)$, and calyculin A (100 nM; $n=5)$. EPSP amplitudes were normalized to the first evoked response. Mean amplitudes of EPSPs $( \pm$ SEM) are plotted versus time. ACSF: $V_{\mathrm{m}}=-76$ to $-92 \mathrm{mV}, 20$ - to 23 -d-old rats; BIC/STRY: $V_{\mathrm{m}}=-74$ to $-85 \mathrm{mV}$, 21- to 26-d-old rats; D-APV: $V_{\mathrm{m}}=-74$ to $-81 \mathrm{mV}, 20$ - to 23-d-old rats; calyculin A: $V_{\mathrm{m}}=-80$ to $-96 \mathrm{mV}, 18$ - to 22-d-old rats.

most effective at stimulation intensities that produce tolerable pain (Walsh et al., 1995; Ward et al., 1996). Thus, this form of counterstimulation excites fine primary afferent nerve fibers, some of which are nociceptors. Transcutaneous electrical nerve stimulation and dorsal root stimulation are often used at higher stimulation frequencies than those used in the present study. In some cases, however, low-stimulation frequencies were found to be more effective than high-stimulation frequencies (Walsh et al., 1995). Finally, physical therapies that use cold or warm stimuli may evoke low-frequency impulses in thermosensitive A $\delta$-fibers. Thus, various clinically effective treatments for the alleviation of pain might lead to an LTD of synaptic transmission between fine primary afferent nerve fibers and neurons in superficial spinal dorsal horn.

\section{REFERENCES}

Artola A, Bröcher S, Singer W (1990) Different voltage-dependent thresholds for inducing long-term depression and long-term potentiation in slices of rat visual cortex. Nature 347:69-72.

Ascher P, Nowak L (1987) Electrophysiological studies of NMDA receptors. Trends Neurosci 10:284-288.

Barnes-Davies M, Forsythe ID (1995) Pre- and postsynaptic glutamate receptors at a giant excitatory synapse in rat auditory brainstem slices. J Physiol (Lond) 488:387-406. 
Bliss TVP, Collingridge GL (1993) A synaptic model of memory: longterm potentiation in the hippocampus. Nature 361:31-39.

Bormann J, Hamill OP, Sakmann B (1987) Mechanism of anion permeation through channels gated by glycine and $\gamma$-aminobutyric acid in mouse cultured spinal neurones. J Physiol (Lond) 385:243-286.

Chung JM, Fang ZR, Cargill CL, Willis WD (1983) Prolonged naloxone-reversible inhibition of the flexion reflex in the cat. Pain 15:35-53.

Chung JM, Lee KH, Hori Y, Endo K, Willis WD (1984) Factors influencing peripheral nerve stimulation produced inhibition of primate spinothalamic tract cells. Pain 19:277-293.

Dudek SM, Bear MF (1992) Homosynaptic long-term depression in area CA1 of hippocampus and effects of $N$-methyl-D-aspartate receptor blockade. Proc Natl Acad Sci USA 89:4363-4367.

Dudek SM, Bear MF (1993) Bidirectional long-term modification of synaptic effectiveness in the adult and immature hippocampus. J Neurosci 13:2910-2918.

Gobel S, Falls WM (1979) Anatomical observations of horseradish peroxidase filled terminal primary axonal arborizations in layer II of the substantia gelatinosa of Rolando. Brain Res 175:335-340.

Handwerker HO, Iggo A, Zimmermann M (1975) Segmental and supraspinal actions on dorsal horn neurons responding to noxious and non-noxious skin stimuli. Pain 1:147-165.

Hartell NA (1996) Strong activation of parallel fibers produces localized calcium transients and a form of LTD that spreads to distant synapses. Neuron 16:601-610.

Honore T, Davies SN, Drejer J, Fletcher EJ, Jacobsen P, Lodge D, Nielsen FE (1988) Quinoxalinediones: potent competitive nonNMDA glutamate receptor antagonists. Science 241:701-703.

Johnston D, Williams S, Jaffe D, Gray R (1992) NMDA-receptorindependent long-term potentiation. Annu Rev Physiol 54:489-505.

Kangrga I, Jiang M, Randić M (1991) Actions of (-)-baclofen on rat dorsal horn neurons. Brain Res 562:265-275.

King AE, Thompson SWN, Urban L, Woolf CJ (1988) The responses recorded in vitro of deep dorsal horn neurons to direct and orthodromic stimulation in the young rat spinal cord. Neuroscience 27:231-242.

Le Bars D, Dickenson AH, Besson JM (1979) Diffuse noxious inhibitory controls (DNIC). I. Effects on dorsal horn convergent neurones in the rat. Pain 6:283-304.

Light AR, Perl ER (1979) Spinal termination of functionally identified primary afferent neurons with slowly conducting myelinated fibers. J Comp Neurol 186:133-150.

Linden DJ (1994) Long-term synaptic depression in the mammalian brain. Neuron 12:457-472.

Lisman J (1989) A mechanism for the Hebb and the anti-Hebb process underlying learning and memory. Proc Natl Acad Sci USA 86:9574-9578.

Lisman J (1994) The CaM kinase II hypothesis for the storage of synaptic memory. Trends Neurosci 17:406-412.

Liu H, Wang H, Sheng M, Jan LY, Jan YN, Basbaum AI (1994) Evidence for presynaptic $N$-methyl-D-aspartate autoreceptors in the spinal cord dorsal horn. Proc Natl Acad Sci USA 91:8383-8387.

Liu X-G, Sandkühler J (1995) Long-term potentiation of C-fiber-evoked potentials in the rat spinal dorsal horn is prevented by spinal $N$-methylD-aspartic acid receptor blockage. Neurosci Lett 191:43-46.

Liu X-G, Sandkühler J (1997) Characterization of long-term potentiation of C-fiber-evoked potentials in spinal dorsal horn of adult rat: essential role of neurokinin 1 and neurokinin 2 receptors. J Neurophysiol, in press.

MacDermott AB, Mayer ML, Westbrook GL, Smith SJ, Barker JL (1986) NMDA-receptor activation increases cytoplasmic calcium concentration in cultured spinal cord neurones. Nature 321:519-522.

Malenka RC, Kauer JA, Zucker RS, Nicoll RA (1988) Postsynaptic calcium is sufficient for potentiation of hippocampal synaptic transmission. Science 242:81-84.

Malenka RC, Kauer JA, Perkel DJ, Mauk MD, Kelly PT, Nicoll RA, Waxham MN (1989) An essential role for postsynaptic calmodulin and protein kinase activity in long-term potentiation. Nature 340:554-557.

Malenka RC, Lancaster B, Zucker RS (1992) Temporal limits on the rise in postsynaptic calcium required for the induction of long-term potentiation. Neuron 9:121-128.
Mayer ML, Westbrook GL (1987) The physiology of excitatory amino acids in the vertebrate central nervous system. Prog Neurobiol 28:197-276.

Melzack R, Wall PD (1965) Pain mechanisms: a new theory. Science 150:971-979.

Mitchell K, Spike RC, Todd AJ (1993) An immunocytochemical study of glycine receptor and GABA in laminae I-III of rat spinal dorsal horn. J Neurosci 13:2371-2381.

Mulkey RM, Malenka RC (1992) Mechanisms underlying induction of homosynaptic long-term depression in area of CA1 of the hippocampus. Neuron 9:967-975.

Mulkey RM, Herron CE, Malenka RC (1993) An essential role for protein phosphatases in hippocampal long-term depression. Science 261:1051-1055.

Neveu D, Zucker RS (1996) Postsynaptic levels of $\left[\mathrm{Ca}^{2+}\right]_{\mathrm{i}}$ needed to trigger LTD and LTP. Neuron 16:619-629.

Pin J-P, Duvoisin R (1995) Neurotransmitter receptors. I. The metabotropic glutamate receptors: structure and functions. Neuropharmacology 34:1-26.

Pinco M, Lev-Tov A (1993) Modulation of monosynaptic excitation in the neonatal rat spinal cord. J Neurophysiol 70:1151-1158.

Pockett S (1995) Long-term potentiation and depression in the intermediate gray matter of rat spinal cord in vitro. Neuroscience 67:791-798.

Polc P, Ducic I (1990) Afferent stimulation frequency modulates GABAergic phenomena in the spinal cord: reversal by benzodiazepine antagonists. Brain Res 531:286-289.

Pomeranz B, Bibic L (1988) Electroacupuncture suppresses a nociceptive reflex: naltrexone prevents but does not reverse this effect. Brain Res 452:227-231.

Pomeranz B, Warma N (1988) Electroacupuncture suppression of a nociceptive reflex is potentiated by two repeated electroacupuncture treatments: the first opioid effect potentiates a second non-opioid effect. Brain Res 452:232-236.

Randić M, Jiang MC, Cerne R (1993) Long-term potentiation and longterm depression of primary afferent neurotransmission in the rat spinal cord. J Neurosci 13:5228-5241.

Schneider SP, Perl ER (1988) Comparison of primary afferent and glutamate excitation of neurons in the mammalian spinal dorsal horn. J Neurosci 8:2062-2073.

Singer W (1995) Development and plasticity of cortical processing architectures. Science 270:758-764.

Sivilotti L, Woolf CJ (1994) The contribution of GABA(A) and glycine receptors to central sensitization: disinhibition and touch-evoked allodynia in the spinal cord. J Neurophysiol 72:169-179.

Urban BJ, Nashold BS (1978) Percutaneous epidural stimulation of the spinal cord for relief of pain. J Neurosurg 48:323-328.

Wagman IH, Price DD (1969) Responses of dorsal horn cells of M. mulatta to cutaneous and sural nerve A and C fiber stimuli. J Neurophysiol 32:803-817.

Walsh DM, Liggett C, Baxter D, Allen JM (1995) A double-blind investigation of the hypoalgesic effects of transcutaneous electrical nerve stimulation upon experimentally induced ischaemic pain. Pain 61:39-45.

Ward L, Wright E, McMahon SB (1996) A comparison of the effects of noxious and innocuous counterstimuli on experimentally induced itch and pain. Pain 64:129-138.

Watkins JC, Evans RH (1981) Excitatory amino acid transmitters. Annu Rev Pharmacol Toxicol 21:165-204.

Woolf CJ, Wall PD (1982) Chronic peripheral nerve section diminishes the primary afferent A-fibre mediated inhibition of rat dorsal horn neurones. Brain Res 242:77-85.

Woolf CJ, Thompson SWN, King AE (1988) Prolonged primary afferent induced alterations in dorsal horn neurones, an intracellular analysis in vivo and in vitro. J Physiol (Paris) 83:255-266.

Yoshimura M, Jessell T (1990) Amino acid-mediated EPSPs at primary afferent synapses with substantia gelatinosa neurones in the rat spinal cord. J Physiol (Lond) 430:315-335.

Yoshimura M, Nishi S (1995) Primary afferent-evoked glycine- and GABA- mediated IPSPs in substantia gelatinosa neurones in the rat spinal cord in vitro. J Physiol (Lond) 482:29-38. 